Studia Oecumenica 17 (2017)

DOI: $10.25167 / \mathrm{SOe} / 17 / 2017 / 287-304$

PRZEMYSŁAW KanTYKA

Wydział Teologii KUL

\title{
Chrzest i Eucharystia w dialogach katolicko-anglikańskich i katolicko-metodystycznych
}

\author{
Baptism and Eucharist \\ in the Catholic-Anglican and Catholic-Methodist Dialogues
}

\begin{abstract}
Theology of baptism never contained such doctrinal controversies, which would have to be solved in the ecumenical dialogues between Catholics and Anglicans, as well as between Catholics and Methodists. This explains limited place given to these questions in the ecumenical talks and documents. Nevertheless, the elements of baptismal doctrine as present in the documents of dialogues allow to state the basic coherence of our respective baptismal theologies. This in consequence gives the basis for mutual recognition of the validity of baptism administrated in the three denominations in question. Besides considerable achievements of the ecumenical dialogues in the domain of the Eucharistic doctrine between Catholics and Anglicans, as well as between Catholics and Methodists, the present degree of consensus still does not allow to establish the full Eucharistic hospitality, not to speak about the full Church unity. The Roman Catholic-Anglican and Roman CatholicMethodist ecumenical dialogues on Eucharist have brought a large degree of convergence and even agreement. However, there still remain unresolved questions, obstructing the restoration of full Eucharistic unity. Thus, further clarification are needed about the notion of Christ's presence and the nature of the Eucharistic change.
\end{abstract}

Keywords: baptism, Eucharist, Catholic-Anglican dialogue, Catholic-Methodist dialogue.

\section{Streszczenie}

Teologia chrztu nie zawierała kontrowersji doktrynalnych, które trzeba by wyjaśniać w dialogach ekumenicznych katolicko-anglikańskim i katolicko-metodystycznym. Dlatego właśnie tematyce tej poświęcono mniej miejsca w dialogach i dokumentach z nich powstałych. Niemniej zawarte w dokumentach dialogu elementy doktryny chrzcielnej pozwalają stwierdzić zasadniczą zbieżność teologii chrztu. W konsekwencji na tej podstawie możemy wzajemnie uznawać chrzest udzielany we wszystkich trzech dialogujących wyznaniach. Pomimo znacznych osiągnięć dialogów ekumenicznych na temat doktryny eucharystycznej, obecny stan uzgodnień pomiędzy anglikanami i katolikami oraz metodystami i katolikami nie pozwala jeszcze na ustanowienie pełnej gościnności eucharystycznej, a tym bardziej pełnej jedności kościelnej. Dialog ekumeniczny katolicko-anglikański i katolicko-metodystyczny na temat Eucharystii przyniósł znaczący stopień konwergencji, a nawet 
zgody. Niemniej wciąż pozostają nierozwiązane kwestie przeszkadzające w odtworzeniu pełnej jedności eucharystycznej. Tak więc potrzebne będą dalsze wyjaśnienia na temat pojmowania obecności Chrystusa w Eucharystii oraz natury przemiany eucharystycznej.

Słowa kluczowe: chrzest, Eucharystia, dialog katolicko-anglikański, dialog katolicko-metodystyczny.

Zarówno doktryna chrzcielna, jak i doktryna eucharystyczna anglikanizmu i metodyzmu są w dużej mierze zbieżne, jako że metodyzm wyrosły z anglikanizmu zasadniczo przejął jego teologiczne dziedzictwo. Od czasu powstania i usamodzielnienia się metodyzmu pod koniec XVIII w. zarówno życie liturgiczne, jak i doktryna zaczęły się kształtować nieco odmiennie. W tym miejscu nie będziemy się jednak zajmować analizą nauki o chrzcie i Eucharystii w obu tych wyznaniach, lecz wynikami dialogów ekumenicznych w tych dziedzinach, toczonych pomiędzy anglikanami i metodystami z Kościołem rzymskokatolickim.

\section{Chrzest w dialogu ekumenicznym katolicko-anglikańskim}

We wspólnych deklaracjach papieży i arcybiskupów Canterbury na przestrzeni wszystkich lat dialogu powtarza się niezmienne sformułowanie: „nasz wspólny chrzest", co można uznać za potwierdzenie przez najwyższych rangą przedstawicieli Kościołów wzajemnego uznania ważności tego sakramentu. Podobne sformułowanie znajdujemy w Raporcie z Malty ${ }^{1}$ z 1966 r. oraz w kolejnych raportach ARCIC (Anglican-Roman Catholic International Commission ${ }^{2}$ ): Eucharistic Doctrine $^{3}$ z 1971 r., Ministry and Ordination ${ }^{4}$ z 1973 r., Authority in the Church I z 1976 r. Wyjaśnienia ${ }^{6}$ do dokumentu Authority in the Church I z 1981 r. zawierają zaczątki wspólnej teologii chrztu: mowa jest tam o świeckich, którzy przez chrzest mają prawo i zdolność do wypełniania w Koście-

1 The Malta Report. Report of the Anglican-Roman Catholic Preparatory Commission, 1968, w: H. MAYER, L. VISHER (red.), Growth in Agreement Reports and Agreed Statements of Ecumenical Conversations on a World Level, New York - Geneva 1984, 120-125.

${ }^{2}$ Komisję powoływała wspólna deklaracja papieża Pawła VI i arcybiskupa Canterbury, wydana w Rzymie 24 marca 1966 r., The Common Declaration by the Pope Paul VI and the Archbishop of Canterbury, w: H. MAYER, L. VISHER (red.), Growth in Agreement, 125-126.

${ }^{3}$ Anglican-Roman Catholic International Commission: An Agreed Statement on Eucharistic Doctrine, London 1972 (dalej: ED).

${ }^{4}$ Anglican-Roman Catholic International Commission: The Agreed Statements: Eucharistic Doctrine 1971, Ministry and Ordination 1973, London 1973.

${ }_{5}$ Authority in the Church. A Statement on the Question of Authority, its Nature, Exercise and Implications Agreed by the Anglican-Roman Catholic International Commission, London 1976.

${ }^{6}$ Authority in the Church I. Elucidation, 1981, w: Anglican-Roman Catholic International Commission. The Final Report, Windsor 1981, London 1982 (dalej: EL). 
le różnorodnych funkcji ${ }^{7}$. We Wprowadzeniu do Raportu Końcowego ARCIC I wskazano na wspólnototwórczą rolę chrztu, nieoddzielnego od wiary i nawrócenia $^{8}$. Więcej teologii chrztu znajdujemy w dokumencie Zbawienie i Kościót ${ }^{9}$ z 1986 r.: przez chrzest jesteśmy w sposób niepowtarzalny złączeni z Chrystusem w Jego śmierci i zmartwychwstaniu. Dzięki mocy Ducha Świętego stajemy się członkami jednego ciała i razem uczestniczymy w życiu Bożym, jesteśmy uwolnieni od grzechu i powstajemy do nowego życia. Również przez chrzest, który jest sakramentem wiary, wchodzimy na drogę zbawienia ${ }^{10}$. Chrzest nawrócenia i wiary - czytamy już w następnym dokumencie ARCIC z 1991 r.: Kościót jako komunia - nie tylko przywraca to, co człowiek utracił przez grzech, ale daje nam w Duchu przystęp do tej jedynej komunii, jaką Chrystus ma ze swoim Ojcem ${ }^{11}$. Na wspólnym chrzcie opiera się wspólnota eklezjalna i w ten sposób chrzest jest jej elementem konstytutywnym ${ }^{12}$. Wspólnota ochrzczonych przyjmuje kanoniczne Pismo Święte jako słowo Boże ${ }^{13}$. Te rozsiane po dokumentach dialogu katolicko-anglikańskiego elementy teologii chrztu nie stanowią spójnego wykładu. Powodem tego jest zasadnicza zbieżność nauki o chrzcie i jego wzajemne uznawanie. Jak bowiem stwierdza dokument Komunia $w$ misji wydany przez IARCCUM ${ }^{14}:$, ,...) niezmiennie przyznajemy, że współdzielimy fundamentalną komunię wspólnej wiary i wspólnego chrztu"15.

W sposób bardziej systematyczny zagadnienie chrztu zostało opisane w dokumencie IARCCUM Wzrastanie w jedności i misji ${ }^{16}$. Dokument zawiera wprost sformułowane stwierdzenie: „Pełne wzajemne uznanie chrztu jest samo w sobie podstawą wzrostu komunii pomiędzy nami" ${ }^{17}$. Otrzymujemy ten sam chrzest,

7 Tamże, 4.

8 Anglican-Roman Catholic International Commission. The Final Report. Windsor 1981, London 1982, Introduction, 8.

9 Salvation and the Church: an Agreed Statement, Salvation and the Church. An agreed Statement by the Anglican-Roman Catholic International Commission, 1986. London 1987, 1, 12, 16 (dalej: SC).

10 Tamże, 25.

${ }^{11}$ Church as Communion. An agreed Statement by the Anglican-Roman Catholic International Commission, 1991, London 1991, 8, 15 (dalej: ChC).

${ }_{12}$ Tamże, 45; Gift of Authority. Authority in the Church III. An Agreed Statement by the Anglican-Roman Catholic International Commission, 1999, London 1999, 14 (dalej: GA).

13 Tamże, 23.

${ }_{14}$ International Anglican-Roman Catholic Commission for Unity and Mission.

15 International Meeting of Anglican and Catholic Bishops. Statement: Communion in Mission, Canada, May 14-20, 2000, http://www.vatican.va/roman_curia/pontifical_councils/chrstuni/anglcomm-docs/rc_pc_chrstuni_doc_20000519_iarccum-mississauga_en.html, 5 (3.04.2017).

${ }^{16}$ Growing Together in Unity and Mission. Building on 40 years of Anglican-Roman Catholic Dialogue. An Agreed Statement by the International Anglican-Roman Catholic Commission for Unity and Mission, 2007, http://www.vatican.va/roman_curia/pontifical_councils/chrstuni/anglcomm-docs/rc_pc_chrstuni_doc_20070914_growing-together_en.html (dalej: GT) (5.04.2017).

17 Tamże, 11. 
którego udziela się przy użyciu wody w imię Ojca, Syna i Ducha Świętego. Chrzest jest ustanowionym przez samego Chrystusa sakramentem inicjacji, włączającym nas w Jego życie i Jego Ciało; jest sakramentem wiary, w którym wierzący przyjmuje wiarę Kościoła i włącza się w Kościół ${ }^{18}$. Potwierdzona też została wspólna dla chrześcijan biblijna nauka o chrzcie, w którym przez wiarę chrześcijanie są włączeni w życie, śmierć i zmartwychwstanie Chrystusa, pogrzebani z Chrystusem, by powstać do nowego życia. Przez chrzest, który jest niepowtarzalny, zostajemy obmyci z grzechów, także z grzechu pierworodnego, oraz bez naszych zasług, a tylko dzięki łasce przyoblekamy się w Chrystusa i otrzymujemy Ducha Świętego. Chrzest zapoczątkowuje odnowę życia i wzrost w świętości ${ }^{19}$. Wreszcie, potwierdzone zostało wcześniejsze stwierdzenie: „Wspólnota Anglikańska i Kościół katolicki uznają wzajemnie chrzest przez siebie udzielany. Anglikanie i katolicy uznają zatem nasz wspólny chrzest za więź i fundament jedności pomiędzy nami" ${ }^{20}$. Komisja IARCCUM zaproponowała też wspólny wymiar praktyczny dotyczący celebracji chrzcielnej: wspólne programy formacyjne do chrztu i materiały katechetyczne, wspólne odnawianie przyrzeczeń chrzcielnych na Zesłanie Ducha Świętego, używanie takich samych metryk chrzcielnych oraz włączanie do celebracji świadków chrztu z drugiej Wspólnoty ${ }^{21}$.

\section{Chrzest w dialogu ekumenicznym katolicko-metodystycznym}

Dialog katolicko-metodystyczny rozpoczął się od spotkania w 1966 r. w Londynie delegacji Kościoła rzymskokatolickiego i Światowej Rady Kościołów Metodystycznych i powołania komisji ds. dialogu ${ }^{22}$. Podobnie jak w przypadku dialogu katolicko-anglikańskiego, nauka o chrzcie nie była polem poważnych kontrowersji. Niemniej, tematykę chrztu poruszono w dialogu w Raporcie z Honolulu $^{23}$ z 1981 r., Raporcie z Nairobi ${ }^{24}$ z 1986 r., Raporcie z Paryża ${ }^{25}$ z 1991 r.,

18 GT, 35.

19 Tamże, 36-37.

20 Tamże, 38.

${ }^{21}$ Tamże, 100.

22 The Joint Commission Between The Roman Catholic Church and The Word Methodist Council (dalej: Komisja).

${ }^{23}$ Honolulu Report, 1981, w: H. MaYer, L. Visher (red.), Growth in Agreement, 367-387 (dalej: $\mathrm{HON})$.

${ }^{24}$ Towards a Statement on the Church, Nairobi, 1986, w: J. Gross, H. Meyer, W.G. Rusch (red.), Growth in Agreement II. Reports and Agreed Statements of Ecumenical Conversations on a World Level 1982-1998, Geneva 2000, 583-596 (dalej: NAI).

${ }^{25}$ Paris Report, 1991, The Apostolic Tradition, w: J. Gross, H. Meyer, W.G. Rusch (red.), Growth in Agreement II, 597-618 (dalej: PAR). 
Raporcie z Rio ${ }^{26}$ z 1996 r., Raporcie z Brighton ${ }^{27}$ z 2001 r. oraz w Raporcie z Seu$l u^{28} \mathrm{z} 2006 \mathrm{r}$. Pełniejsze i bardziej systematyczne opracowanie tematyki chrzcielnej znalazło się w najnowszym Raporcie z Durban ${ }^{29}$ z 2011 r., w którym zebrano elementy teologii chrzcielnej obecne we wcześniejszych dokumentach.

Wspólnie katolicy i metodyści zgadzają się, że chrzest jest z ustanowienia Bożego $^{30}$, że jest pierwszym i podstawowym sakramentem Ewangelii ${ }^{31}$, a dokonuje się w wierze otrzymanej od Apostołów, głoszonej przez wspólnotę i jej

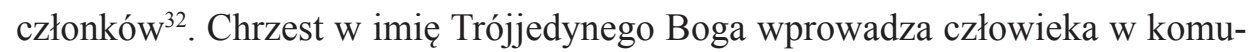
nię z Chrystusem i jednocześnie w te relacje, które konstytuują wspólnotę wiary - Kościół Chrystusa ${ }^{33}$.

Wprowadzenie do wspólnoty wierzących poprzez chrzest, identyfikujący ochrzczonego ze śmiercią i zmartwychwstaniem Chrystusa, oznacza również uwolnienie od więzów grzechu i śmierci ${ }^{34}$, a także umożliwia człowiekowi wejście do wspólnoty eucharystycznej ${ }^{35}$. Ci, którzy przez wody chrztu zostali włączeni w życie Boga, mają udział w szczególnych więzach miłości zadzierzgniętych przez Ducha Świętego pomiędzy Osobami Boskimi a stworzeniem. Ochrzczeni stają się w ten sposób rodziną Bożą, a pomiędzy sobą - braćmi i siostrami, dzieląc przywileje i odpowiedzialność wynikającą z chrztu ${ }^{36}$. Przez chrzest wspólnota wierzących ma też udział w świętości samego Boga. Świętość ta manifestuje się poprzez prawdziwie chrześcijańskie życie wiernego ochrzczonego ${ }^{37}$.

Chrzest, zanurzający nas w wodzie oczyszczenia, jest sakramentem wiary ${ }^{38}$, znakiem nowego życia, które Ojciec daje nam przez Chrystusa w Duchu Świę-

${ }^{26}$ Rio de Janeiro Report, 1996, The Word of Life: A Statement on Revelation and Faith, w: J. Gross, H. Meyer, W.G. Rusch (red.), Growth in Agreement II, 618-646 (dalej: RIO).

27 Brighton Report, 2001, Speaking the Truth in Love. Teaching Authority among Catholics and Methodists. Report of The Joint Commission Between The Roman Catholic Church and The Word Methodist Council 1997-2001. Seventh Series, New York 2001 (dalej: BRI).

${ }_{28}$ Seoul Report, 2006, The Grace given You in Christ. Catholics and Methodists Reflect Further on the Church. Report of the International Commission for Dialogue Between the Roman Catholic Church and the World Methodist Council, Lake Junaluska 2006 (dalej: SEO).

${ }^{29}$ Encountering Christ the Saviour: Church and Sacraments. Ninth Report of the International dialogue between the World Methodist Council and the Roman Catholic Church. Durban, 2011, http://www.vatican.va/roman_curia/pontifical_councils/chrstuni/meth-council-docs/rc_pc_chrstuni_doc_20110612_durban-document_en.html(dalej: DUR) (7.03.2017).

${ }^{30}$ NAI 13.

${ }^{31}$ NAI 12; RIO 102.

32 PAR 63.

33 PAR 46; RIO 50; SEO 61; DUR 7, 17, 22, 62-66.

${ }^{34}$ PAR 40; DUR 28, 31-32.

${ }^{35}$ RIO 100, 118.

36 PAR 64.

${ }^{37}$ PAR 65, 67; DUR 30.

38 DUR 32, 34, 36, 37, 40. 
tym $^{39}$. Również przez chrzest wszczepiający w Chrystusa wierni - indywidualnie oraz jako wspólnota wierzących - uczestniczą w Jego urzędzie kapłańskim, prorockim i królewskim. Otrzymują namaszczenie Duchem Świętym, który poucza ich i prowadzi do całej prawdy ${ }^{40}$. Namaszczenie Duchem Świętym rozpoczyna w wierzącym relację ze wspólnotą, która prowadzona jest przez tego samego Ducha i aktywnie uczestniczy w akcie chrztu ${ }^{41}$. Chrzest też od samego początku chrześcijaństwa był okazją do złożenie wyznania wiary, które później ujęto w znane dziś formuły, szczególnie w symbol nicejsko-konstantynopolitański ${ }^{42}$.

Zarówno katolicy, jak i metodyści uważają za słuszne udzielać chrztu dzieciom zrodzonym z wierzących rodziców, choć mają świadomość, że pierwotną formą chrztu był chrzest dorosłych, mogących złożyć wyznanie wiary ${ }^{43}$. Jednocześnie zachęcają, aby zarówno ochrzczeni w dzieciństwie, jak w wieku dojrzałym korzystali z okazji do odnowienia przyrzeczeń składanych na chrzcie ${ }^{44}$. Ponieważ zaś wezwanie Boże jest nieodwołalne, tak katolicy, jak metodyści nie powtarzają chrztu, w którym zostali opieczętowani (sealed) przez Ducha Świętego, podobnie jak nie powtarzają bierzmowania i święceńn ${ }^{45}$.

Tak w Kościele katolickim, jak w Kościołach metodystycznych chrztu udziela się przez zanurzenie w wodzie bądź polanie nią w imię Ojca, Syna i Ducha Świętego. Metodyści i katolicy używają w rycie chrzcielnym tradycyjnego języka biblijnego, mówiącego o ojcowskiej miłości Boga, zbawczym dziele Chrystusa i włączeniu w Jego Ciało, o mocy Ducha Świętego, nawróceniu i odpuszczeniu grzechów, o wierze i odrodzeniu do nowego życia ${ }^{46}$. Katolicy w wielu miejscach na świecie uznają chrzest udzielony w Kościołach metodystycznych, podobnie jak metodyści uznają chrzest udzielony w Kościele rzymskokatolickim i nigdy nie chrzczą ponownie w przypadku konwersji katolika na metodyzm ${ }^{47}$. Wspólnie rozumieją chrzest udzielany w imię Ojca, Syna i Ducha Świętego jako sakramentalną więź jedności, widzialny fundament głębokiej komunii, która już istnieje pomiędzy nami ${ }^{48}$ i pobudza nas do pogłębiania jedności, a także udziału w życiu i misji samego Chrystusa ${ }^{49}$. Trudno przecenić doniosłość powyższej deklaracji,

\footnotetext{
39 PAR 40, 63-64; DUR 45-54.

40 PAR 26; BRI 36 (por. KKK 91); DUR 91.

${ }^{41}$ BRI 46.

${ }^{42}$ PAR 16, 38, 63; RIO 43, 84.

43 DUR 30, 42.

${ }^{44}$ PAR 63; DUR 30.

${ }^{45}$ HON 33; PAR 85; DUR 44, 56.

${ }^{46}$ DUR 30.

47 SEO 109; DUR 29.

48 RIO 10; BRI 55; SEO 153-154.

49 SEO 78; DUR 29.
} 
ponieważ uznanie ważności chrztu jest podstawą do uznania eklezjalności danej wspólnoty ${ }^{50}$. Wspólny chrzest z wody i w imię Trójcy Świętej jest nie tylko podstawą dialogu pomiędzy katolikami a metodystami ${ }^{51}$, lecz pociąga za sobą dalsze praktyczne implikacje w życiu eklezjalnym, szczególnie w duszpasterskiej posłudze rodzinom o katolicko-metodystycznej przynależności wyznaniowej ${ }^{52}$. Chodzi tu m.in. o wydawanie metryk chrzcielnych dla rytów mających się odbyć w drugim wyznaniu, o możliwość udziału duchownego jednego wyznania w celebracjach sprawowanych dla rodziny mieszanej w drugim wyznaniu, a także o możliwość otrzymania błogosławieństwa w miejsce przyjęcia Eucharystii podczas Wieczerzy Pańskiej drugiego wyznania ${ }^{53}$.

Metodyści widzą w chrzcie udzielanym przez katolików wejście w przymierze z Bogiem, które jednocześnie pociąga za sobą zaangażowanie się w życie wspólnoty wiary ${ }^{54}$. Katolicy ze swej strony mogą ubogacić się metodystycznym postrzeganiem chrztu nie jako rzeczywistości raz dokonanej, statycznej, lecz jako nieustannego dynamizmu przymierza, które może i powinno być regularnie odnawiane ${ }^{55}$. Dla jednych i drugich świadomość wspólnego chrztu stanowi wezwanie, aby bez wszelkiej niejednoznaczności dopełnić komunię chrzcielną poprzez Komunię eucharystyczną przy jednym stole Pańskim. Takiej bowiem jedności wspólnie poszukujemy ${ }^{56}$.

\section{Eucharystia w dialogu ekumenicznym katolicko-anglikańskim}

Pierwszym dokumentem, jaki opracowała i przyjęła Komisja ARCIC, była deklaracja na temat Eucharystii: Wspólna deklaracja na temat nauki o Eucharystii. Do deklaracji na temat Eucharystii Komisja ARCIC dołączyła w późniejszym czasie Wyjaśnienia (Elucidations) z 1979 r., a następnie Wyjaśnienia (Clarifications) $^{57}$ z 1994 r. Dołączenie pierwszych Wyjaśnień było owocem krytyki, jaką Komisja otrzymała wkrótce po opublikowaniu deklaracji nt. Eucharystii, tak że mogły się one znaleźć razem z deklaracją w tzw. Raporcie Końcowym

50 SEO 105; DUR 55.

51 SEO 144.

${ }^{52}$ SEO 155.

53 SEO 155.

54 SEO 110; DUR 43.

55 SEO 126; DUR 44.

${ }^{56}$ RIO 10.

${ }^{57}$ Clarifications of certain aspects of the agreed statements on Eucharist and Ministry of the First Anglican-Roman Catholic International Commission together with a letter from Cardinal Edward Cassidy, President of the Pontifical Council for Promoting Christian Unity, London - Vatican 1994 (dalej: CL). 
(The Final Report ${ }^{58} \mathrm{z}$ pierwszego etapu prac ARCIC. Konieczność opracowania kolejnych Wyjaśnień (z 1994 r.) spowodowana była potrzebą ustosunkowania się Komisji do oficjalnej katolickiej odpowiedzi na Raport Końcowy ${ }^{59}$.

Zamierzeniem Komisji nie było opracowanie wyczerpującego traktatu na temat Eucharystii, lecz skupienie się na najważniejszych zagadnieniach, uważanych w historii naszych relacji za punkty teologicznych kontrowersji, jednak bez pomijania kwestii istotnych. Komisja uznała bardzo wysoki stopień osiągniętego konsensusu, nadając mu rangę substancjalnej zgody ${ }^{60}$.

Wśród poruszonych tematów pierwszym było zagadnienie ofiarniczego charakteru Eucharystii, czyli w jaki sposób krzyżowa ofiara Chrystusa jest obecna w Eucharystii. Ofiara krzyżowa Chrystusa, Jego śmierć i zmartwychwstanie stwierdza Komisja - dokonały się w sensie historycznym raz i na zawsze ${ }^{61}$. Ofiara ta jest doskonała i wystarczająca, Eucharystia nie jest więc ani jej powtórzeniem, ani dopełnieniem. Dla wyjaśnienia tego zagadnienia Komisja wyeksponowała biblijno-patrystyczny termin anamneza (anamnesis). Spotykamy go zarówno w biblijnych opisach Ostatniej Wieczerzy (Łk 22,19; 1 Kor 11,24-25), jak i w Pierwszej Apologii św. Justyna Męczennika ${ }^{62}$. Dzięki temu terminowi możliwe jest ujęcie relacji Eucharystii do ofiary Chrystusa jako anamnezy - skutecznej pamiątki uobecniającej w sprawowanej Eucharystii raz na zawsze dokonaną jedyną ofiarę śmierci i zmartwychwstania naszego Pana ${ }^{63}$. Użycie kategorii anamnesis, jak się wydaje, pozwala uniknąć zarówno niebezpieczeństwa symbolicznego rozumienia obecności Chrystusa w Eucharystii, jak i wrażenia powtarzalności Ofiary krzyżowej ${ }^{64}$. W ten sposób potwierdzenie znajduje zarówno nauka Soboru Trydenckiego, jak i wczesnoanglikańska doktryna eucharystyczna. Ponadto Komisja stwierdza wyraźnie, że jedyna ofiara Chrystusa obecna jest w sprawowaniu Eucharystii na sposób sakramentalny, co dokonuje się mocą działania Ducha Świętego $0^{65}$.

Na prośbę strony katolickiej Komisja dołączyła wyjaśnienie na temat charakteru przebłagalnego ofiary eucharystycznej. Ofiara ta jest obecna ze wszystkimi jej skutkami i obejmuje cały Kościół: zarówno żyjących, jak i zmarłych, toteż może być również za nich sprawowana. Komisja wykazała przy tym obecność w an-

58 Anglican-Roman Catholic International Commission. The Final Report. Windsor 1981, London 1982.

${ }^{59}$ Katolicka odpowiedź na „Raport Końcowy” Międzynarodowej Komisji Anglikańsko-Rzymskokatolickiej, OsRomPol 7 (1992), 51-54.

${ }^{60} \mathrm{ED}$, Preface.

${ }^{61}$ ED 5.

${ }^{62}$ EL 5.

63 ED 5.

${ }^{64}$ CL 5.

${ }^{65}$ EL 5. 
glikańskich tekstach liturgicznych wyrażeń wskazujących wprost na przebłagalny charakter jedynej ofiary Chrystusa, skutecznie uobecnianej w Eucharystii ${ }^{66}$.

Istotne uzgodnienie dotyczyło też sposobu obecności Chrystusa w Eucharystii. Obecność tę dostrzega Komisja w zgromadzeniu, w słowie Bożym, w osobie wyświęconego (ordynowanego) szafarza oraz w eucharystycznych elementach. Ten ostatni rodzaj obecności, najpełniejszy, zasługuje na szczególną uwagę Komisji. Obecność Chrystusa w konsekrowanych elementach określa się przymiotnikami: „prawdziwa” (true presence) oraz „,rzeczywista” (real presence) ${ }^{67}$. Obecność ta nie zależy od wiary przyjmującego, jednak tylko dzięki wierze staje się nie tylko obecnością „dla wierzącego”, ale obecnością „z wierzącym”. Toteż, stwierdza Komisja, rozważając tajemnicę obecności Chrystusa w Eucharystii, należy uznać zarówno sakramentalny znak obecności Chrystusa, jak też osobisty związek wierzącego z Panem, rodzący się z tej obecności ${ }^{68}$.

W tekście deklaracji Eucharistic Doctrine Komisja odnotowała katolicką naukę o transsubstancjacji, choć nota ta została umieszczona w przypisie. Stało się tak dlatego, że teologowie ARCIC starali się uniknąć używania terminów związanych tradycyjnie z jedną konfesją, i również tradycyjnie odrzucanych przez drugą. Poszukiwali natomiast nowego języka, zdolnego wznieść się ponad terminologię utożsamianą konfesyjnie, aby na tym poziomie spróbować wyrazić wspólną wiarę ${ }^{69}$. ARCIC odczytuje rozumienie terminu „transsubstancjacja” jako afirmację obecności Chrystusa oraz tajemniczej i radykalnej przemiany w wewnętrznej rzeczywistości elementów ${ }^{70}$. Zamiast więc terminu „przeistoczenie” (transsubstantiation), znalazło się w dokumencie stwierdzenie, że „prawdziwa” (true) obecność Chrystusa jest „skutecznie oznaczana” (effectually signified) w chlebie i winie, które w tym misterium „stają się” (become) Jego Ciałem i Krwią przez działanie Ducha Świętego ${ }^{71}$.

Odstąpienie od trydenckiej terminologii spowodowało falę krytyki ze strony katolickiej. Podnoszono argument, że użyte przez Komisję naturalistyczne terminy: to become (stać się) oraz change (przemiana) nie oddają właściwie istoty eucharystycznej transformacji. W Elucidations powrócono więc do tego zagadnienia, uściślając, że termin become nie oznacza zmiany materialnej, według ziemskich praw fizycznych, ani nie ogranicza obecności Chrystusa do kon-

${ }^{66}$ CL 5-6.

${ }^{67}$ ED 6.

${ }^{68}$ ED 8.

${ }^{69}$ CL 7.

${ }^{70}$ Komisja utrzymuje ponadto, że we współczesnej teologii rzymskokatolickiej nie uważa się, aby termin transubstantiation mówił o tym, w jaki sposób eucharystyczna przemiana się dokonuje. ED 6, przypis 2.

${ }^{71}$ ED 6, 10. 
sekrowanych elementów. Natomiast termin ten ma mieć znaczenie afirmujące obecność sakramentalną, w której Bóg posługuje się rzeczywistością ziemską, aby udzielić nam rzeczywistości nowego stworzenia: chleb ziemski „staje się” (becomes) chlebem życia wiecznego ${ }^{72}$.

Nie odrzucając więc katolickiego sposobu wyjaśnienia natury przemiany eucharystycznej przez transsubstancjację, ARCIC proponuje podejście do zagadnienia przemiany eucharystycznej nie od strony rozpatrywania sposobu dokonywania się tej przemiany, lecz od strony wyznania wiary poszczególnego wiernego. Przed modlitwą eucharystyczną wierzący na pytanie: „Co to jest?” powinien odpowiedzieć: „To jest chleb”. Natomiast po modlitwie eucharystycznej na to samo pytanie powinien odpowiedzieć: „To jest prawdziwie Ciało Chrystusa, Chleb Życia"’3.

Sporo problemów przysporzyło Komisji wyjaśnienie zagadnienia kultu Eucharystii poza celebracją Wieczerzy Pańskiej, szczególnie przechowywania rezerwy eucharystycznej oraz adoracji. W pierwszym dokumencie (Eucharistic Doctrine) znalazło się stwierdzenie, że dar obecności Chrystusa nie powinien być oddzielany od eucharystycznego posiłku. Ciało i Krew Chrystusa są bowiem w Eucharystii rzeczywiście obecne po to, aby przez ich pożywanie wierzący mógł zjednoczyć się w komunii z Chrystusem Panem ${ }^{74}$. Dokument nie zawierał jednak żadnego rodzaju afirmacji katolickiej praktyki kultu adoracyjnego. Wątek ten został więc podjęty w wyjaśnieniach z 1979 r. (Elucidations). Komisja przyznaje, że przechowywanie rezerwy eucharystycznej dla Komunii chorych i nieobecnych jest bardzo starą praktyką, sięgającą czasów św. Justyna Męczennika. Późniejszy jednak rozwój praktyki pobożnościowej dotyczącej kultu przechowywanych postaci stwierdza Komisja - niekiedy całkowicie oddzielających adorację od celebracji eucharystycznej stanowi zaprzeczenie prawdziwej doktryny eucharystycznej ${ }^{75}$. Elucidations przywołują także Instrukcję Kongregacji Nauki Wiary z 1967 r. Eucharistici Misterium dla wyjaśnienia, iż adoracja Chrystusa w konsekrowanych postaciach jest przedłużeniem modlitwy uwielbienia rozpoczętej już w sprawowaniu Wieczerzy Pańskiej. Ta zaś modlitwa adoracyjna skierowana jest zawsze do Ojca przez Chrystusa oraz w Chrystusie i w Duchu Świętym. Pomimo jednak tego wyjaśnienia, Komisja zmuszona była przyznać, że dla niektórych adoracja Chrystusa w rezerwie eucharystycznej jest całkowicie niedopuszczalna.

Pojawiła się więc konieczność dalszych wyjaśnień, o które poprosiła strona katolicka. Zawarte one zostały w Clarifications z 1994 r. Tym razem Komisja

\footnotetext{
${ }^{72}$ EL 6b.

${ }^{73}$ EL 6b; CL 6-7.

74 ED 9.

${ }^{75}$ EL 8.
} 
wyraźnie przypomina, że praktyka przechowywania konsekrowanych postaci dla chorych, umierających i nieobecnych jest obecna zarówno w Kościele rzymskokatolickim, jak i anglikańskim ${ }^{76}$. Praktyka ta jest potwierdzeniem doktryny rzeczywistej obecności Chrystusa w Eucharystii. Punktem kontrowersji nie jest jednak doktryna i praktyka przechowywania rezerwy eucharystycznej, lecz związane z nią formy pobożności, kultywowane przez katolików, a nieobecne w anglikanizmie. ARCIC stanęła tu na stanowisku, że różnice w praktykach pobożnościowych nie implikują różnic w doktrynie. W Kościołach wschodnich nigdy przecież nie rozwinęły się formy kultu Eucharystii poza Boską Liturgią, a wiara w obecność Chrystusa w Eucharystii pozostaje od wieków ta sama zarówno na Wschodzie, jak na Zachodzie. Komisja zapewnia więc, że nie ma niebezpieczeństwa zaprzeczania rzeczywistej obecności Chrystusa nawet przez tych anglikanów, którzy niechętni są praktykom pobożnościowym związanym z tą sakramentalną obecnością ${ }^{77}$. Natomiast sama rezerwa eucharystyczna jest przez anglikanów otaczana należytym szacunkiem ${ }^{78}$.

Celem wytyczonym przez Komisję było nie tylko przybliżenie wspólnej wiary w Eucharystię, lecz osiągnięcie zgodności prowadzącej w prostej linii do jedności w wierze. Można stwierdzić, że w dużej mierze zadanie to zostało zrealizowane. Wyjaśniono bowiem główne punkty kontrowersji pomiędzy naszymi tradycjami - anglikańską i rzymskokatolicką. Pewna odmienność ujęć w nauce o Eucharystii, a co za tym idzie, różnice we wrażliwości i języku teologicznym, nie stanowią już zasadniczej przeszkody do ustanowienia wzajemnej uznawalności tego sakramentu i gościnności eucharystycznej. Pozostające na tej drodze problemy należą już do innych zagadnień. Są nimi: kwestia właściwego szafarza Eucharystii, implikująca wzajemne uznanie posługiwania duchownego i święceń oraz problemy natury eklezjologicznej: apostolskości Kościoła i komunii z Biskupem Rzymu jako elementem konstytutywnym Kościoła.

\section{Eucharystia w dialogu ekumenicznym katolicko-metodystycznym}

Już pierwszy wypracowany przez Komisję dialogu katolicko-metodystycznego dokument - Raport z Denver z 1971 r. - odnosił się do problematyki związanej z Eucharystią. W następnym przedłożeniu - Raporcie z Dublina ${ }^{79}$ z 1976 r. znalazło się rozszerzenie opracowania z pierwszego dokumentu, które przybrało

76 CL 7.

${ }^{77}$ CL 7.

${ }^{78}$ CL 8. DUB).

79 Dublin Report, 1976, w: H. MAYER, L. VISHER (red.), Growth in Agreement, 340-366 (dalej: 
formę wspólnego katolicko-metodystycznego uzgodnienia na temat Eucharystii. Uzgodnienie to nie stanowi odrębnego dokumentu, lecz zawarte jest w raporcie obejmującym pięcioletni okres pracy Komisji. Odniesienia do nauki o Eucharystii znalazły się także w Raporcie z Nairobi z 1986 r. oraz w Raporcie z Brighton z 2001 r., a także w najnowszym Raporcie z Durban z 2011 r., w którym w sposób systematyczny opracowano zagadnienie Eucharystii, zbierając elementy dialogu rozsiane we wcześniejszych dokumentach.

Choć dialog katolików z metodystami na temat Eucharystii toczył się równolegle do dialogu katolicko-anglikańskiego, oba dialogi w pierwszej fazie nie były od siebie zależne. W Raporcie z Denver sporządzono właściwie jedynie swego rodzaju listę punktów wspólnych nauki o Eucharystii dla katolicyzmu i metodyzmu, jak też listę zagadnień, w których Komisja stwierdziła wyraźną różnicę. Najwięcej miejsca poświęcono zagadnieniom obecności Chrystusa w Eucharystii oraz ofiarniczego charakteru Eucharystii. Tematyka ta została zasadniczo powtórzona i doprecyzowana w Raporcie z Dublina. Tym razem Komisja korzystała już z uzgodnienia ARCIC, Eucharistic Doctrine z 1971 r. Podstawową trudnością w porównywaniu katolickiej i metodystycznej doktryny eucharystycznej okazał się fakt, że metodyzm nigdy nie był zmuszony wypracować systematycznej eucharystologii, więc jego doktryna eucharystyczna istnieje raczej pod postacią niezdefiniowanych tradycji, niż oficjalnych sformułowań ${ }^{80}$. Powstaniu metodyzmu bowiem nie towarzyszył żaden konflikt doktrynalny ani z katolicyzmem, ani $\mathrm{z}$ anglikanizmem. Brak historycznych obciążeń stanowił jednak faktor ułatwiający dialog doktrynalny ${ }^{81}$.

Raport z Dublina określa Eucharystię jako sakrament Ewangelii, jako najpełniejszy dar miłości Boga w Chrystusie Jezusie przez moc Ducha Świętego. Eucharystia jest upamiętnieniem (commemoration) ofiarniczej śmierci i zmartwychwstania Chrystusa oraz jednoczy nas z Nim w samoofiarowaniu się Ojcu. Przez naszą odpowiedź wiary i miłości zostajemy odnowieni jako członkowie Jego Ciała i uzyskujemy udział w Jego misji. Jest wreszcie Eucharystia antycypacją ostatecznego zwycięstwa Chrystusa i naszego w nim udziału ${ }^{82}$.

Zarówno katolicy, jak i metodyści przyjmują podstawowy fakt obecności w Eucharystii (tj. Mszy św. czy Wieczerzy Pańskiej) Chrystusa ukrzyżowanego i zmartwychwstałego, w pełni Jego bóstwa i człowieczeństwa ${ }^{83}$. Obecność ta nie zależy od osobistego doświadczenia wiernego przystępującego do Komunii, choć może on ją dostrzec jedynie przez wiarę. Przekazywana jest ona poprzez

\footnotetext{
${ }^{80}$ DUB 51, 71.

${ }^{81}$ DUB 48.

${ }^{82}$ DUB 52; DUR 122-127.

${ }^{83}$ DEN 83; DUB 54.
} 
uświęcone elementy chleba i wina, nad którymi wypowiedziano słowa ustanowienia. Eucharystyczne chleb i wino określone zostały jako „skuteczne znaki Ciała i Krwi Chrystusa", w kontekście celebracji eucharystycznej oznaczają one bowiem Ciało i Krew Chrystusa dla oczu naszej wiary ${ }^{84}$. Raport z Dublina dodatkowo przytacza i reafirmuje stwierdzenia Uzgodnienia z Windsor (Eucharistic Doctrine): Chrystus jest obecny i działa na różny sposób w całej celebracji eucharystycznej, zaś komunia z Chrystusem w Eucharystii zakłada Jego prawdziwą obecność, skutecznie oznaczaną przez chleb i wino ${ }^{85}$.

Dla metodystów afirmacja rzeczywistej obecności Chrystusa w Eucharystii wynika z wiary w rzeczywisty udział wiernego, który przyjmuje elementy chleba i wina, w Ciele i Krwi Chrystusa ${ }^{86}$. Widoczna jest tu odziedziczona z anglikanizmu doktryna rzeczywistego udziału (real partaking) komunikującego w Ciele i Krwi Chrystusa.

Raport z Denver odnotowywał różnicę pomiędzy katolikami i metodystami w pojmowaniu obecności Chrystusa w Eucharystii i ujął ją w następujący sposób: dla metodystów obecność Chrystusa w Eucharystii nie różni się fundamentalnie od Jego obecności w innych środkach łaski, np. w przepowiadaniu, któremu niektórzy przyznają nawet pierwszeństwo ${ }^{87}$. Raport z Dublina natomiast unika przeciwstawiania obecności Chrystusa w Eucharystii innym formom Jego obecności, szczególnie obecności w przepowiadanym słowie. Gdziekolwiek Chrystus jest obecny, stwierdza dokument, jest obecny w całej pełni ${ }^{88}$. Na potwierdzenie wiary katolików w obecność Chrystusa w zwiastowaniu słowa Bożego Raport przytacza Konstytucję o liturgii świętej Soboru Watykańskiego II, omawiającą różne sposoby obecności Pana w celebracji eucharystycznej ${ }^{89}$.

Obydwa Raporty (z Denver i Dublina) odnotowują trudności w sformułowaniu wspólnego stanowiska dotyczącego zagadnienia przemiany eucharystycznej. Dla katolików chleb i wino w kontekście eucharystycznej celebracji, poprzez wypowiedzenie słów ustanowienia przez ważnie wyświęconego kapłana, zostają przemienione w inną rzeczywistość, tj. w Ciało i Krew uwielbionego Pana, przy czym zewnętrzna rzeczywistość, tj. fizyczne i chemiczne komponenty chleba i wina, pozostaje niezmieniona ${ }^{90}$. Nawet unikające trydenckiego języka sformułowania katolicko-anglikańskiego uzgodnienia z Windsor (Eucharistic Doctrine), mówiące o „tajemniczej i radykalnej przemianie” wewnętrznej rze-

\footnotetext{
${ }^{84}$ DEN 83; DUB 54; DUR 82.

${ }^{85}$ DUB 55.

${ }^{86}$ DUB 57.

87 DEN 84.

${ }^{88}$ DUB 56.

${ }^{89}$ DUB 58; DUR 80.

${ }^{90}$ DEN 84; DUB 59; DUR 83.
} 
czywistości elementów, które „stają się Ciałem i Krwią Chrystusa”, mogą być zaakceptowane przez metodystów jedynie w tym sensie, że chleb i wino uzyskują dodatkowe znaczenie jako skuteczne znaki Ciała i Krwi Chrystusa. Przemiana ta jednak nie powoduje, że chleb przestaje być chlebem, a wino winem ${ }^{91}$. Takie podejście metodystów wzbudza uzasadnione obawy o koherencję postrzegania eucharystycznej przemiany przez obie dialogujące strony.

W sprawie kultu Eucharystii poza celebracją liturgiczną Raport z Denver stwierdzał jedynie, że kult Najświętszego Sakramentu jest związany z katolicką doktryną o przemianie elementów i nie ma zastosowania w metodyzmie ${ }^{92}$. Raport z Dublina traktuje tę kwestię afirmatywnie, zaznaczając, że przechowywanie konsekrowanych postaci - najpierw w celu Komunii chorych, potem w celu adoracji - wynika z wiary w rzeczywistą obecność. Metodyści, choć nie mają zwyczaju przechowywania, to odnoszą się do konsekrowanych elementów z szacunkiem ${ }^{93}$.

Przy wyraźnych różnicach w doktrynie rzeczywistej obecności Raport z Denver zawiera stwierdzenie daleko idącej zgodności co do ofiarniczego charakteru Eucharystii, choć terminologia „ofiarnicza” nie jest używana w metodyzmie. Jej nieobecność w liturgicznych tekstach metodyzmu tłumaczy się pochodzeniem tychże wprost z anglikańskiej Book of Common Prayer. Stało się tak pomimo faktu, że bracia Wesleyowie nawiązywali w swych pismach i hymnach do Eucharystii jako ofiary ${ }^{94}$.

W Raporcie z Denver Eucharystia zostaje określona jako „celebracja pełnej, doskonałej i wystarczającej ofiary Chrystusa, dokonanej raz na zawsze, za cały świat”, jako „pamiątka (memorial) będąca czymś więcej niż wspomnieniem (recollection) przeszłych wydarzeń” i jako „ponowne ogłoszenie (re-enactment) triumfalnej ofiary Chrystusa, które udostępnia nam jej korzyści" ${ }^{95}$. W Raporcie z Dublina na dookreślenie angielskiego memorial przywołano termin anamnesis, którym wcześniej posłużyła się Komisja ARCIC ${ }^{96}$.

Zarówno katolicy, jak i metodyści używają języka ofiarniczego przede wszystkim w odniesieniu do raz na zawsze dokonanej ofiary Chrystusa, następnie do naszego udziału w tej ofierze, do ofiary chwały i dziękczynienia, jaką składamy, oraz do ofiary z nas samych w jedności z Chrystusem, który ofiarował się Ojcu ${ }^{97}$. Katolicy ponadto zwykli mówić o „ofierze mszalnej”. Nawet jednak, gdy wy-

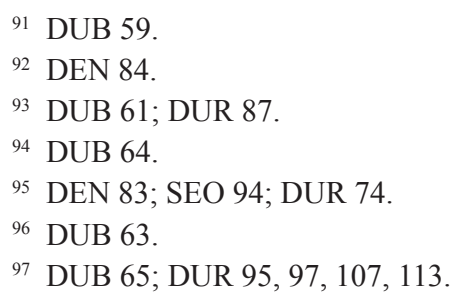


jaśniają, że nie chodzi o powtarzanie raz na zawsze dokonanej ofiary Chrystusa, ale o jej sakramentalne uobecnienie, niektórzy metodyści wciąż widzą w tym sformułowaniu ideę ciągłego ofiarowywania Chrystusa. Dlatego wolą mówić, że Chrystus raz się ofiarowawszy teraz żyje, aby się wstawiać za nami ${ }^{98}$.

W najnowszym Raporcie z Durban strony stwierdzają: „Eucharystia jest celebracją pełnej, doskonałej i wystarczającej ofiary Chrystusa, złożonej raz na zawsze za cały świat. Jest to pamiątka nie będąca tylko zwykłym przywoływaniem w pamięci przeszłych wydarzeń lub ich znaczenia, ale skutecznym proklamowaniem przez Kościół wielkiego dzieła Chrystusa. W celebracji tej rzeczywiście mamy udział w samoofiarowaniu się Chrystusa w posłuszeństwie woli Ojca" ${ }^{99}$. Wyjaśniono też, kogo należy uważać za składającego ofiarę: „Na pytanie «Kto składa ofiarę Eucharystyczną?» metodyści i katolicy razem odpowiadają: «Chrystus, nasza Głowa, zjednoczony ze swym Ciałem, Kościołem»"100.

Komisja odnotowała również zgodność w pojmowaniu znaczenia przystępowania do Komunii, które jest najdoskonalszym sposobem uczestnictwa w celebracji eucharystycznej: przez udział w Ciele i Krwi Chrystusa stajemy się jedno z Nim oraz wzajemnie ze sobą ${ }^{101}$. Rozbieżność natomiast odnotowano w podejściu do zagadnienia interkomunii: podczas gdy metodyści zapraszają do stołu Pańskiego wszystkich mogących w sumieniu przyjąć to zaproszenie, katolicy poza wypadkami naglącymi - ograniczają to zaproszenie jedynie do wyznających tę samą, co oni, wiarę ${ }^{102}$. Raport $z$ Dublina zawiera doprecyzowanie tego zagadnienia. Choć praktyka zapraszania do stołu Pańskiego „wszystkich, którzy kochają Pana Jezusa Chrystusa”, była i jest często spotykana we wspólnotach metodystycznych, to jednak nie oznacza to, że metodyzm powszechnie akceptuje tę praktykę jako normę generalną. Normą pozostaje bowiem dopuszczanie do Komunii osób ochrzczonych oraz komunikowanie we własnej wspólnocie wyznaniowej ${ }^{103}$. Dla niekatolików natomiast pragnących przyjąć Komunię św. w Kościele katolickim wymaganie wyznawania tej samej, co katolicy, wiary eucharystycznej nie oznacza jedynie zwykłej afirmacji rzeczywistej obecności Chrystusa w Eucharystii, lecz zakłada przyjęcie całej doktryny eucharystycznej Kościoła katolickiego ${ }^{104}$.

\footnotetext{
98 DUB 66; DUR 98.

99 DUR 93; por. DEN 83; DUB 63.

${ }^{100}$ DUR 114; por. DUR 118-119, 131-134.

101 DEN 83.

102 DEN 84.

${ }^{103}$ DUB 68.

${ }^{104}$ DUB 70.
} 
Daleko posunięta zbieżność teologii sakramentu chrztu pozwalała już od dawna na wzajemne uznawanie ważności tego sakramentu udzielanego w Kościele katolickim, w Kościołach Wspólnoty Anglikańskiej oraz Kościołach metodystycznych. Prowadzone dialogi nie wykazały żadnych poważnych kontrowersji, jedynie różne rozkładanie akcentów w teologii chrzcielnej. Pozwala to na formułowanie postulatów o wspólnym przeprowadzaniu przygotowania do chrztu, wzajemnym zapraszaniu świadków oraz ujednoliceniu metryk chrzcielnych.

Dialogi doktrynalne na temat Eucharystii przyniosły zróżnicowane owoce. Dalej posunięty jest dialog katolicko-anglikański, w którym deklarowano nawet substancjalną zgodę. Problemem pozostaje akceptacja wypracowanego stanowiska szczególnie przez anglikański tzw. Low Church, bliższy poglądom kalwińskim, niż katolickim. Więcej trudności do rozwiązania pozostaje w dialogu rzymskiego katolicyzmu z metodyzmem. Przejęcie przez metodyzm kalwinizujących poglądów anglikańskich, jeszcze sprzed narodzin anglokatolicyzmu, stawia w centrum uwagi zagadnienie realnej obecności Chrystusa w Eucharystii. Również późniejszy rozwój praktyki sakramentalnej w metodyzmie przyniósł m.in. trudność w postaci zmiany materii Eucharystii: dopuszczenie chleba z ziarna innego niż pszeniczne oraz nieużywanie wina, lecz niesfermentowanego soku winogronowego, a nawet $\mathrm{z}$ innych owoców.

Niebagatelną kwestią, na razie nie eksplorowaną w dialogach, jest ordynowanie kobiet do posługi duchownej we wspólnotach anglikańskich i metodystycznych. Określenie właściwego szafarza sakramentu ma bowiem istotne znaczenie przy uznawaniu jego ważności.

\section{Bibliografia}

Anglican-Roman Catholic International Commission. The Final Report. Windsor 1981, London 1982.

Anglican-Roman Catholic International Commission. The Final Report. Windsor 1981, London 1982.

Anglican-Roman Catholic International Commission: An Agreed Statement on Eucharistic Doctrine, London 1972.

Anglican-Roman Catholic International Commission: The Agreed Statements: Eucharistic Doctrine 1971, Ministry and Ordination 1973, London 1973. Authority in the Church I. Elucidation, 1981, w: Anglican-Roman Catholic International Commission. The Final Report, Windsor 1981, London 1982. 
Authority in the Church. A Statement on the Question of Authority, its Nature, Exercise and Implications Agreed by the Anglican-Roman Catholic International Commission, London 1976.

Brighton Report, 2001. Speaking the Truth in Love. Teaching Authority among Catholics and Methodists. Report of The Joint Commission Between The Roman Catholic Church and The Word Methodist Council 1997-2001. Seventh Series, New York 2001.

Church as Communion. An agreed Statement by the Anglican-Roman Catholic International Commission, 1991, London 1991.

Clarifications of certain aspects of the agreed statements on Eucharist and Ministry of the First Anglican-Roman Catholic International Commission together with a letter from Cardinal Edward Cassidy, President of the Pontifical Council for Promoting Christian Unity, London - Vatican 1994.

Common Declaration by the Pope Paul VI and the Archbishop of Canterbury, w: H. Mayer, L. Visher (red.), Growth in Agreement. Reports and Agreed Statements of Ecumenical Conversations on a World Level, New York Geneva: WCC Publications 1984, s. 125-126.

Dublin Report, 1976, w: H. MAYer, L. Visher (red.), Growth in Agreement. Reports and Agreed Statements of Ecumenical Conversations on a World Level, New York - Geneva: WCC Publications 1984, s. 340-366.

Encountering Christ the Saviour: Church and Sacraments. Ninth Report of the International dialogue between the World Methodist Council and the Roman Catholic Church. Durban, 2011, http://www.vatican.va/roman_curia/pontifical_councils/chrstuni/meth-council-docs/rc_pc_chrstuni_ doc_20110612_durban-document_en.html (7.03.2017).

Gift of Authority. Authority in the Church III. An Agreed Statement by the Anglican-Roman Catholic International Commission, 1999, London 1999.

Growing Together in Unity and Mission. Building on 40 years of Anglican-Roman Catholic Dialogue. An Agreed Statement by the International Anglican-Roman Catholic Commission for Unity and Mission, 2007, http://www. vatican.va/roman_curia/pontifical_councils/chrstuni/angl-comm-docs/rc pc_chrstuni_doc_20070914_growing-together_en.html (5.04.2017).

Honolulu Report, 1981, w: H. Mayer, L. Visher (red.), Growth in Agreement. Reports and Agreed Statements of Ecumenical Conversations on a World Level, New York - Geneva: WCC Publications 1984, s. 367-387.

International Meeting of Anglican and Catholic Bishops. Statement: Communion in Mission, Canada, May 14-20, 2000, http://www.vatican.va/roman_curia/pontifical_councils/chrstuni/angl-comm-docs/rc_pc_chrstuni_ doc_20000519_iarccum-mississauga_en.html, 5 (3.04.2017). 
Katolicka odpowiedź na „Raport Końcowy” Międzynarodowej Komisji Anglikańsko-Rzymskokatolickiej, „L'Osservatore Romano” 7 (1992), s. 51-54.

Malta Report. Report of the Anglican-Roman Catholic Preparatory Commission, 1968, w: H. Mayer, L. Visher (red.), Growth in Agreement. Reports and Agreed Statements of Ecumenical Conversations on a World Level, New York - Geneva: WCC Publications 1984, s. 120-125.

Paris Report, 1991. The Apostolic Tradition, w: J. Gross, H. Meyer, W.G. Rusch (red.), Growth in Agreement II. Reports and Agreed Statements of Ecumenical Conversations on a World Level 1982-1998, Geneva: WCC Publications 2000, s. 597-618.

Rio de Janeiro Report, 1996. The Word of Life: A Statement on Revelation and Faith, w: J. Gross, H. Meyer, W.G. Rusch (red.), Growth in Agreement II. Reports and Agreed Statements of Ecumenical Conversations on a World Level 1982-1998, Geneva: WCC Publications 2000, s. 618-646.

Salvation and the Church: an Agreed Statement, Salvation and the Church. An agreed Statement by the Anglican-Roman Catholic International Commission, 1986, London 1987.

Seoul Report, 2006. The Grace given You in Christ. Catholics and Methodists Reflect Further on the Church. Report of the International Commission for Dialogue Between the Roman Catholic Church and the World Methodist Council, Lake Junaluska 2006.

Towards a Statement on the Church, Nairobi, 1986, w: J. Gross, H. MeYer, W.G. Rusch (red.), Growth in Agreement II. Reports and Agreed Statements of Ecumenical Conversations on a World Level 1982-1998, Geneva: WCC Publications 2000, s. 583-596. 